\title{
Karakterisasi FTIR pada Studi Awal Penumbuhan CNT dengan Prekursor Nanokatalis Ag dengan Metode HWC-VHF-PECVD
}

\author{
Ajeng Eliyana ${ }^{1, *}$ dan Toto Winata ${ }^{2}$ \\ ${ }^{1}$ Prodi Fisika, Jurusan Sains, Institut Teknologi Sumatera, \\ Jl. Terusan Ryacudu, Jati Agung, Lampung Selatan, Lampung, 35365 \\ ${ }^{2}$ Kelompok Keahlian Fisika Material Elektronik, Prodi Fisika, Fakultas Matematika dan Ilmu Pengetahuan Alam, \\ Institut Teknologi Bandung, Jl. Ganesha 10, Bandung, 40132 ${ }^{\dagger}$
}

\section{Intisari}

Telah dilakukan penumbuhan carbon nanotubes (CNT) menggunakan nano-katalis perak sebagai pemandu di atas substrat gelas Corning 7059 dengan metode evaporasi. Penumbuhan dilakukan dengan waktu deposisi 50, 25, dan 14 sekon, diikuti proses annealing pada temperatur $400^{\circ} \mathrm{C}$ selama 4 jam. Karakterisasi morfologi nano-katalis Ag menggunakan SEM dan EDX. Studi selanjutnya adalah penumbuhan lapisan tipis CNT di atas substrat nano-katalis Ag dengan metode Hot wire Cell-Very High Frequency Plasma Enhance Chemical Vapour Deposition (HWC-VHF-PECVD) pada temperatur deposisi $275^{\circ} \mathrm{C}$ dan tekanan 300 mTorr. Daya rf divariasikan dari 8 sampai 20 watt, dengan waktu deposisi selama 60 menit. Sumber karbon yang digunakan adalah gas metan $99,999 \%$. Gas hidrogen digunakan untuk mengetsa lapisan oksida yang mungkin terbentuk selama proses pra-deposisi. Diameter dan panjang CNT di atas Ag/CG 7059 masing-masing 250-393 nm dan 309-376 $\mathrm{nm}$, untuk sebaran partikel yang masih berbentuk bundel. Sedangkan diameter dan panjang untuk partikel yang berbentuk tube masing-masing $125 \mathrm{~nm}$ dan 1,650-2,989 $\mu \mathrm{m}$. Pada daya rf 8 dan 10 watt terlihat adanya material CNT tumbuh dengan arah tegak lurus terhadap permukaan substrat dan sejajar permukaan substrat. Karakterisasi selanjutnya pada penumbuhan lapisan tipis CNT ini yaitu menggunakan Fourier Transform Infra Red (FTIR). Pada daya rf 8 dan 10 watt menunjukkan adanya gugus fungsi $\mathrm{C}=\mathrm{C}$ dan pada daya 20 watt menunjukkan gugus fungsi C-C.

\begin{abstract}
The study of CNT growth has been done by using silver (Ag) nanocatalyst as a precursor guide on the corning glass 7059 substrate by the use of the evaporation method. The growth were done by varying deposition times for 50,25 , and 14 seconds, then followed by the annealing process at temperature of $400^{\circ} \mathrm{C}$ for 4 hours. The characterization of Ag nanocatalyst morphology were done by using SEM and EDX. The CNT thin films of growth on the Ag nanocatalyst substrate was then deposited by the Hot wire Cell-Very High Frequency Plasma Enhance Chemical Vapour Deposition (HWC-VHF-PECVD) method, at deposition temperature of $275^{\circ} \mathrm{C}$ and pressure of 300 mTorr. The rf power was varied from 8 to 20 watts, with deposition time for 60 minutes. The 99.999\% methane $\left(\mathrm{CH}_{4}\right)$ gas was used as Carbon sources. The hydrogen gas $\left(\mathrm{H}_{2}\right)$ was used to etch the oxide layer formed during the pre-deposition process. The CNTdiamater and length for on the Ag/CG 7059 were 250 to $393 \mathrm{~nm}$ and 309 to $376 \mathrm{~nm}$, respectively, for the cluster distribution of particles. Meanwhile, for the tubes particle (CNT) the diameter and length were $125 \mathrm{~nm}$ and 1.650 to $2.989 \mu \mathrm{m}$, respectively. At the rf power of 8 and 10 watts, the CNTs were vertical and horizontal shape on the substrate surface. The CNT thin films growth were further characterized using Fourier Transform Infra Red (FTIR). The rf power of 8 and 10 watts results showed the $\mathrm{C}=\mathrm{C}$ and $\mathrm{C}-\mathrm{C}$ cluster, and $\mathrm{C}-\mathrm{C}$ cluster at 20 watts
\end{abstract}

KATA KUNCI: Ag nanocatalyst, evaporation, FTIR, CNT, HWC-VHF-PECVD http://dx.doi.org/10.12962/j24604682.v13i2.2155

\section{PENDAHULUAN}

Belakangan ini pembentukan nano-katalis logam yang berperan sebagai pemandu proses penumbuhan CNT banyak menarik perhatian peneliti. Y.Y. Wei, et al. [1] telah

\footnotetext{
*E-MAIL: eliyanaajeng13@gmail.com
}

${ }^{\dagger}$ E-MAIL: toto@fi.itb.ac.id melakukan eksperimen untuk melihat pengaruh ketebalan lapisan katalis logam terhadap pertumbuhan CNT. Hasil eksperimen diperoleh bahwa ada korelasi yang signifikan antara diameter CNT yang dideposisikan pada reaktor PECVD dengan ukuran partikel katalis [1].

Upaya penumbuhan CNT pada dasarnya telah dilakukan di Laboratorium kelompok keahlian Fisika Material Elektronik ITB dengan menggunakan pengembangan teknik PECVD yang dimodifikasi yang dikenal dengan nama HWC-VHFPECVD. Dengan menggunakan metode ini, telah berhasil di- 


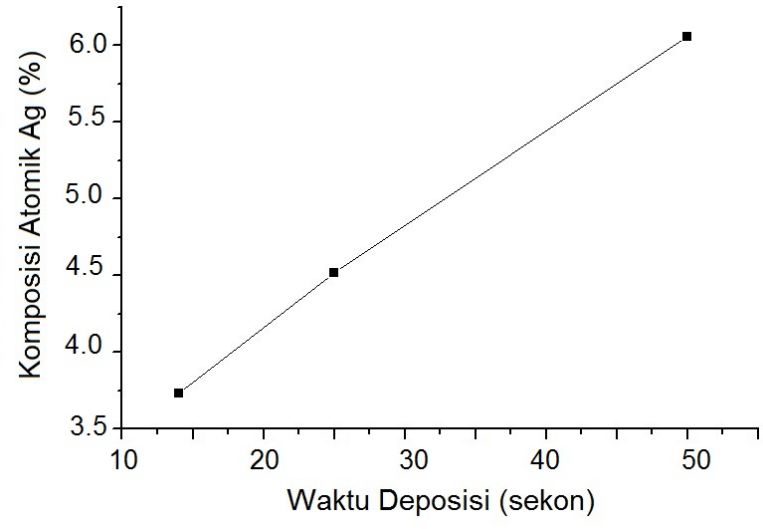

Gambar 1: Hubungan komposisi atomik Ag dan waktu deposisi evaporasi dengan suhu annealing $400^{\circ} \mathrm{C}$ selama 4 jam.

tumbuhkan lapisan tipis CNT di atas katalis $\mathrm{Al} / \mathrm{CG}, \mathrm{Al} / \mathrm{Si}$ (100), dan $\mathrm{Ni} / \mathrm{Si}(100)$ pada temperatur rendah $275^{\circ} \mathrm{C}$ dan tekanan chamber rendah 300 mTorr [2]. Pengembangan selanjutnya yaitu dengan teknik HWC-VHF-PECVD di atas nanokatalis Ag/CG 7059 pada daya rf yang telah divariasikan dari 8 sampai 20 watt, dengan waktu deposisi selama 60 menit [3]. Teknik ini menggunakan tambahan filamen panas sebagai pengurai gas methane $\left(\mathrm{CH}_{4}\right)$ yang dicampur dengan gas hidrogen sebagai gas sumber, sehingga molekul-molekul gas yang mencapai daerah substrat sudah berbentuk radikalradikal yang lebih sederhana.

Berdasar pertimbangan hasil penelitian tersebut, dalam makalah ini dipaparkan karakterisasi FTIR untuk penumbuhan material CNT dengan teknik HWC-VHF-PECVD dan hanya menggunakan nano-katalis monolayer. Karakterisasi menggunakan FTIR bertujuan untuk mengetahui gugus fungsi yang dibentuk oleh CNT dengan nano-katalis Ag dan gas methane $\left(\mathrm{CH}_{4}\right)$ yang dicampur dengan gas hidrogen sebagai gas sumber sebagai pengurai. Laju deposisi optimum akan diperoleh dengan menvariasikan daya rf yang berperan sebagai sumber pembangkit plasma. Melalui teknik ini diharapkan dapat dihasilkan CNT pada temperatur rendah.

\section{EKSPERIMEN}

Dalam penelitian ini, penumbuhan nano-katalis Ag di atas substrat gelas Corning 7059 menggunakan metode evaporasi dengan variasi waktu penumbuhan, yaitu 50, 25, dan 14 sekon.

Salah satu proses yang dilakukan yaitu proses annealing. Proses annealing nano-katalis Ag dilakukan dengan alat furnace tube selama 4 jam dalam temperatur $400^{\circ} \mathrm{C}$. Proses annealing ini dilakukan untuk membentuk pulau-pulau (islands) sehingga ukuran dari nano-katalis Ag dapat terbentuk.

Proses yang terakhir adalah penumbuhan lapisan tipis CNT di atas substrat nano-katalis Ag akan dilakukan dengan metode HWC-VHF-PECVD. Parameter yang digunakan dalam penumbuhan CNT yaitu temperatur deposisi $275^{\circ} \mathrm{C}$, tekanan 300 mTorr, laju aliran gas $80 \mathrm{sccm}$, temperatur HWC
TABEL I: Komposisi atomik (\%) dalam variasi waktu deposisi.

\begin{tabular}{cccccc}
\hline \hline Waktu deposisi & \multicolumn{5}{c}{ Komposisi atomik (\%) } \\
(sekon) & $\mathrm{O}$ & $\mathrm{Si}$ & $\mathrm{Al}$ & $\mathrm{Ba}$ & $\mathrm{Ag}$ \\
\hline 50 & 41,57 & 33,39 & 8,82 & 8,16 & 6,06 \\
25 & 49,51 & 30,82 & 7,05 & 6,89 & 4,52 \\
14 & 51,31 & 30,80 & 7,77 & 5,67 & 3,73 \\
\hline \hline
\end{tabular}

$800^{\circ} \mathrm{C}$, waktu deposisi selama 60 menit, dan daya rf yang divariasikan dari 20 sampai 8 watt. Sumber karbon yang digunakan adalah gas metan $\left(\mathrm{CH}_{4}\right) 99,999 \%$. Gas hidrogen $\left(\mathrm{H}_{2}\right)$ dialirkan selama proses pra-deposisi untuk mengikis lapisan oksida yang terbentuk. Lapisan tipis CNT yang terbentuk kemudian dikarakterisasi untuk mengetahui keberadaan material CNT. Karakterisasi yang dilakukan dalam penelitian ini adalah pengukuran SEM, EDX, dan UV-Vis [3] dan karakterisasi selanjutnya yaitu FTIR.

\section{HASIL DAN PEMBAHASAN}

Sampel nano-katalis Ag yang telah diannealing selanjutnya dikarakterisasi untuk mengetahui morfologi permukaan dan diameter nano-katalis yang telah ditumbuhkan menggunakan SEM. Nano-katalis Ag yang ditumbuhkan berdasarkan variasi waktu penembakan katalis Ag sampai menempel di substrat [3].

Perlakuan temperatur dan waktu yang sama ketika annealing, memungkinkan sampel dengan katalis Ag yang lebih banyak memerlukan energi yang lebih besar untuk membentuk pulau-pulau, berbeda dengan sampel dengan katalis Ag yang lebih sedikit, energi yang diperlukan lebih rendah sehingga clusters dari nano-katalis Ag dapat terbentuk lebih baik. Penurunan komposisi atomik Ag terhadap berkurangnya waktu deposisi evaporasi ditunjukkan pada Tabel I dan Gambar 1. Selain menunjukkan komposisi atomik Ag, Tabel I menunjukkan pula komposisi substrat yang digunakan yaitu gelas Corning 7059 yang dikarakterisasi menggunakan SEMEDX.

Berdasarkan Gambar 1 terlihat komposisi atomik Ag yang lebih meningkat dengan bertambahnya waktu deposisi. Tetapi sebaran ukuran untuk setiap sampel nano-katalis yang ditumbuhkan pada 50, 25, dan 14 sekon tidak merata, sebaran ukuran kecil sampai sebaran ukuran yang besar dimungkinkan material Ag yang terbentuk. Kemungkinan ini hanya dapat dibuktikan dengan penumbuhan CNT. Sebaran ukuran untuk sampel dengan waktu deposisi 14 sekon memperlihatkan sebaran ukuran yang lebih homogen [4].

Penelitian selanjutnya yaitu penumbuhan CNT dengan metode HWC di luar daerah gas masuk tepatnya diantara dua elektroda, dan nano-katalis yang digunakan adalah nanokatalis Ag dengan waktu penumbuhan 14 sekon. Pemilihan waktu penumbuhan 14 sekon karena memberikan sebaran ukuran yang lebih homogen [5-8].

Pada sampel pertama yaitu material CNT yang ditumbuhkan dengan daya rf 8 watt yang ditunjukkan pada Gambar 2, terlihat material tumbuh dengan arah tegak lurus ter- 


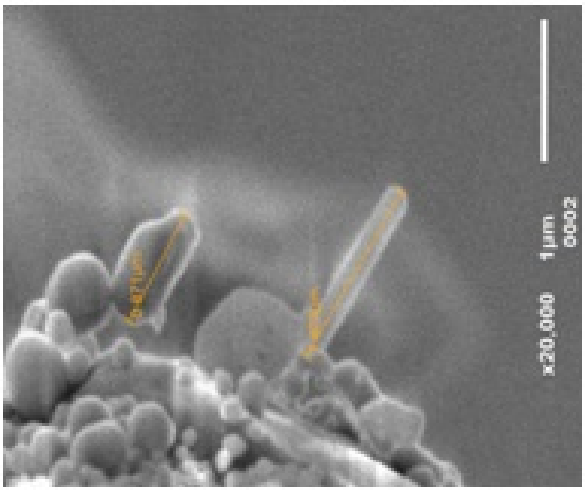

Gambar 2: Hasil SEM CNT/Ag/CG 7059 dengan daya rf 8 watt.

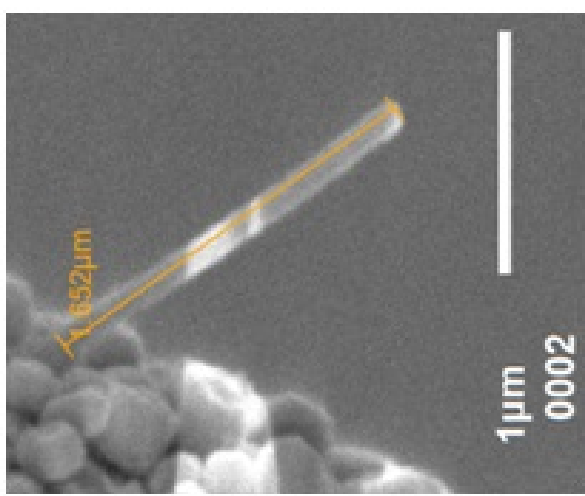

Gambar 3: Hasil SEM CNT/Ag/CG 7059 dengan daya rf 10 watt.

hadap permukaan substrat. Bentuk CNT yang lurus di atas permukaan substrat menunjukkan ciri-ciri CNT yang ditumbuhkan oleh sistem PECVD. Hal ini disebabkan energi listrik di dalam plasma cukup besar untuk meluruskan tabung CNT tersebut [9].

Daya rf 10 watt yang ditunjukkan pada Gambar 3, sebaran partikel masih berbentuk bundel dengan diameter dan panjangnya masing-masing $299 \mathrm{~nm}$ dan $328 \mathrm{~nm}$. Sedangkan diameter dan panjang untuk partikel yang berbentuk tube (CNT) masing-masing $125 \mathrm{~nm}$ dan $1,65 \mathrm{~m}$. Pada daya 20 watt (Gambar 4) material CNT yang tumbuh masih berbentuk bundel, tidak homogen, dan tidak terlihat adanya material yang berbentuk tube. Diameter dan panjangnya masing-masing 250 $\mathrm{nm}$ dan $309 \mathrm{~nm}$.

Pemberian daya rf yang lebih tinggi membantu dalam mekanisme penguraian gas yang lebih efektif, tetapi daya rf yang terlalu tinggi menyebabkan gas lebih energetik sehingga menimbulkan terbentuknya radikal-radikal terionisasi dalam plasma. Radikal-radikal ionik tersebut dalam batas tertentu akan berfungsi sebagai pengetsa kimiawi (chemical-etching) yang dapat mengikis permukaan lapisan yang telah terbentuk, yang biasa dikenal dengan bombardemen ion. Selain itu, radikal-radikal tersebut akan tumbuh di daerah yang tidak mengandung katalis, sehingga dikhawatirkan dengan kelebihan karbon akan membentuk carbon amorf.

Berbeda dengan hasil karakterisasi morfologi dengan

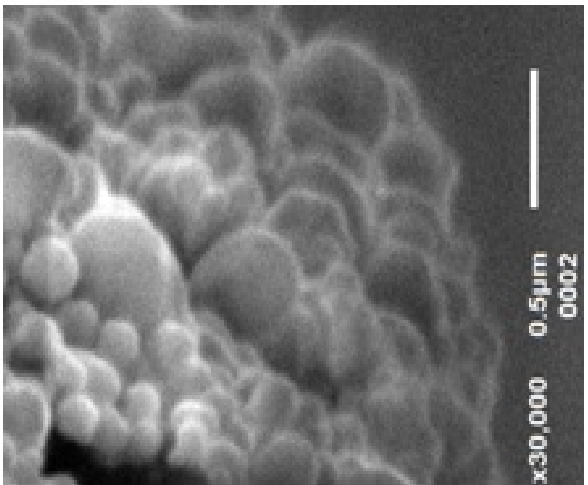

Gambar 4: Hasil SEM CNT/Ag/CG 7059 dengan daya rf 20 watt.

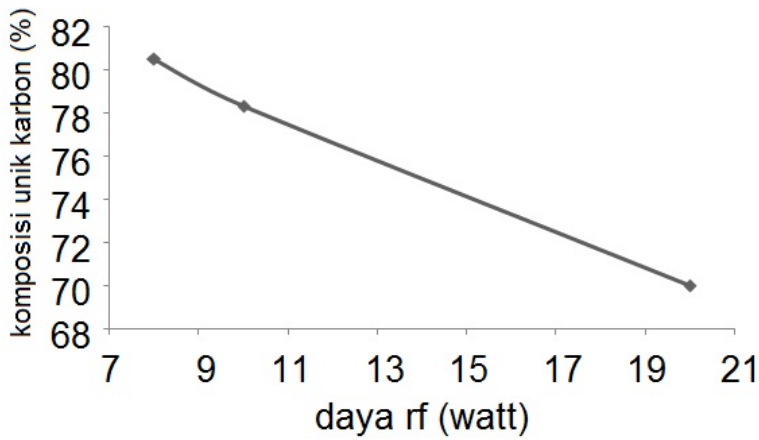

Gambar 5: Hubungan komposisi atomik C dan daya rf.

menggunakan SEM, ketiga sampel yang dihasilkan mempunyai diameter dan panjang yang berbeda pula sesuai dengan perubahan daya rf yang diberikan, hasil penumbuhan CNT ditunjukkan lebih terperinci pada Tabel II.

Morfologi lapisan CNT sangat bergantung pada morfologi dan jumlah nano-katalis yang dideposisi, waktu penumbuhan CNT dan tekanan di dalam chamber. Setelah dilakukan optimasi sebelumnya, nano-katalis Ag yang digunakan dalam penumbuhan CNT ini adalah nano-katalis dengan waktu deposisi 14 sekon. Ukuran sebaran diameternya adalah 33 $\mathrm{nm}, 65 \mathrm{~nm}, 394 \mathrm{~nm}$. Sedangkan sebaran ukuran diameter dari CNT yang dihasilkan adalah 250-393 nm untuk CNT yang berbentuk bundel dan $125 \mathrm{~nm}$ untuk CNT yang berbentuk tube dengan panjang tube 1,650-2,989 $\mu \mathrm{m}$. Hasil ini sesuai dengan sebaran diameter ukuran yang besar pada nano-katalis Ag. Untuk sebaran ukuran diameter yang kecil tidak dapat dilihat karena keterbatasan alat SEM yang digunakan.

TABEL II: Hasil Penumbuhan CNT dan komposisi persentase atomik karbon terhadap variasi daya rf yang berbeda.

\begin{tabular}{cccccc}
\hline \hline \multirow{2}{*}{$\begin{array}{c}\text { Daya } \\
\text { rf }\end{array}$} & \multicolumn{2}{c}{ Diameter } & \multicolumn{2}{c}{ Panjang } & \multicolumn{2}{c}{ Komposisi } \\
tabung & $(\mathrm{nm})$ & \multicolumn{2}{c}{ tabung $(\mathrm{nm})$} & atomik C \\
(watt) & Bundel & Tube & Bundel & Tube & $(\%)$ \\
\hline 8 & 393 & 125 & 376 & 2989 & 80,52 \\
10 & 299 & 125 & 328 & 1650 & 78,35 \\
20 & 250 & - & 309 & - & 70,02 \\
\hline \hline
\end{tabular}




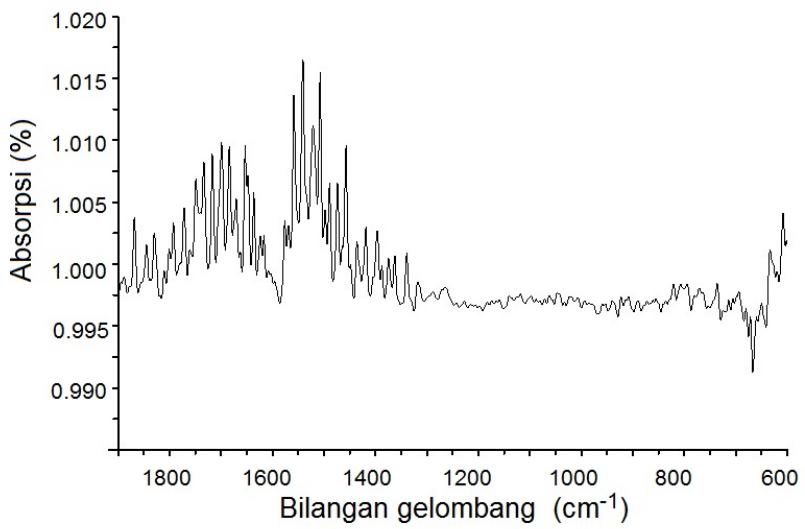

(a) daya if 8 watt

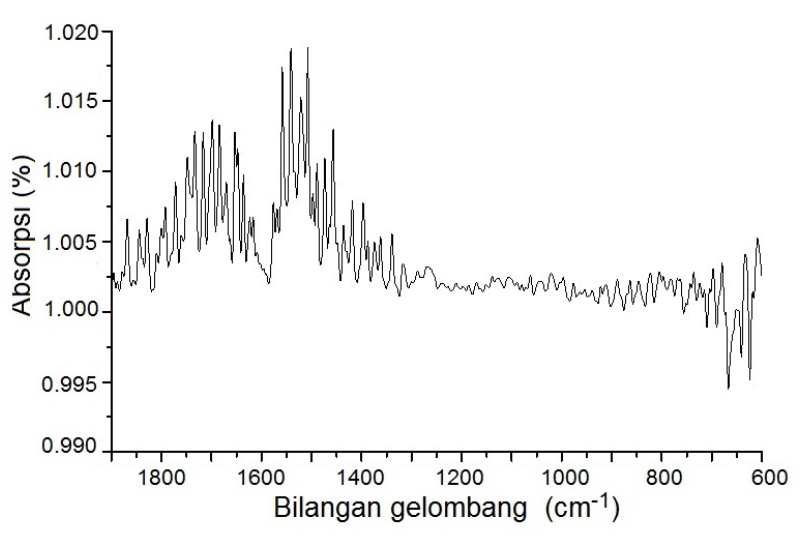

(b) daya rf 10 watt

Gambar 6: Hasil FTIR CNT/Ag/CG 7059.

Hubungan komposisi atomik karbon dengan variasi daya rf ditunjukkan pada Gambar 5, dan dari gambar tersebut terlihat penurunan komposisi karbon dengan bertambahnya daya rf.

Karakterisasi selanjutnya adalah menggunakan spektrofotometer FTIR, dengan prinsip kerja yang digunakan yaitu melihat adanya interaksi energi berupa sinar infrared de-ngan materi berupa senyawa kompleks yang mengakibatkan molekul-molekul bervibrasi.

Vibrasi dapat terjadi karena energi yang berasal dari sinar infrared tidak cukup kuat untuk menyebabkan terjadinya eksitasi elektron pada molekul yang ditembak dimana besarnya energi vibrasi tiap atom atau molekul berbeda tergantung pada atom-atom dan kekuatan ikatan yang menghubungkannya sehingga dihasilkan frekuensi yang berbeda pula.

Hasil analisis (Gambar 6) menunjukkan adanya gugus fungsi $\mathrm{C}=\mathrm{C}$ yang merupakan gugus dari cincin benzen untuk penumbuhan CNT pada daya rf 8 dan 10 watt, dimana pergeseran bilangan gelombang terjadi pada kisaran 1500$1600 \mathrm{~cm}^{-1}$, pada panjang gelombang ini merupakan daerah ikatan rangkap dua. Selain itu terdapat pula bilangan gelombang pada kisaran $1000-1300 \mathrm{~cm}^{-1}$ yang merupakan vibrasi ulur C-C, dan bilangan gelombang pada kisaran 700-1000 $\mathrm{cm}^{-1}$ merupakan vibrasi tarik C-C [10].

Sedangkan pada Gambar 7 menunjukkan hasil FTIR CNT/Ag/CG 7059 yang ditumbuhkan pada daya 20 watt, terdapat bilangan gelombang pada kisaran $1000-1300 \mathrm{~cm}^{-1}$ yang merupakan puncak vibrasi ulur $\mathrm{C}-\mathrm{C}$, dimana vibrasi ini akan mengakibatkan perubahan panjang suatu ikatan dan bilangan gelombang pada kisaran $700-1000 \mathrm{~cm}^{-1}$ merupakan puncak vibrasi tarik C-C, yang mengakibatkan perubahan sudut ikatan antara dua ikatan. Pada daya rf ini tidak terlihat adanya puncak gugus fungsi $\mathrm{C}=\mathrm{C}$, dimungkinkan karena pemberian daya rf yang terlalu tinggi yang menyebabkan gas lebih energetik sehingga menimbulkan terbentuknya

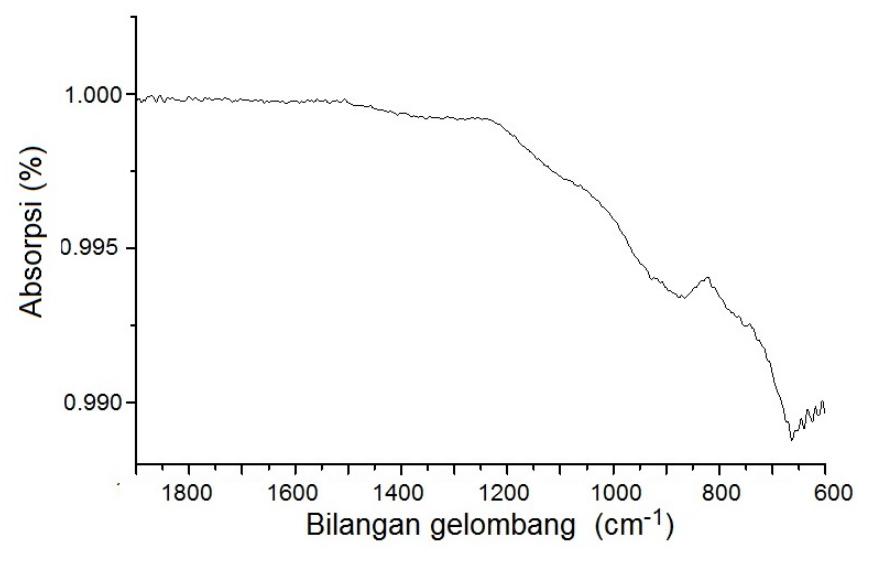

Gambar 7: Hasil FTIR CNT/Ag/CG 7059 dengan daya rf 20 watt.

radikal-radikal terionisasi dalam plasma. Radikal-radikal ionik tersebut dalam batas tertentu akan berfungsi sebagai pengetsa kimiawi (chemical-etching) yang dapat mengikis permukaan lapisan yang telah terbentuk.

\section{SIMPULAN}

Telah berhasil ditumbuhkan nano-katalis Ag dengan variasi waktu penembakan katalis Ag yaitu 50, 25, dan 14 sekon di atas substrat gelas Corning 7059, pada temperatur annealing $400^{\circ} \mathrm{C}$ selama 4 jam. Sehingga dapat dikatakan waktu penembakan 14 detik sudah cukup baik untuk pembentukan nano-katalis logam $\mathrm{Ag}$, dan dapat digunakan sebagai prekursor untuk deposisi CNT dengan metode HWC-VHF-PECVD dan berdasarkan karakterisasi FTIR menunjukkan adanya kandungan atau gugus fungsi $\mathrm{C}-\mathrm{C}$ dan $\mathrm{C}=\mathrm{C}$, dan hasil penelitian ini menunjukkan $\mathrm{CNT}$ sudah dapat diperoleh dengan HWC-VHF-PECVD pada daya rendah. 
[1] Y.Y. Wei, G. Eres, V.I. Merkulov, and D.H. Lowndes, App.Phys.lett., 78, 1394-1396 (2001).

[2] A. Latununuwe, Penumbuhan Carbon Nanotube dengan Metode Hot Wire Cell-Very High Frequency-Plasma Enhanced Chemical Vapor Deposition, Disertasi ITB. Bandung, 2011.

[3] A. Eliyana, A. Rosikin, and T. Winata, Initial Study of CNT Growth using Nanocatalyst Ag Precursor by $H W C-V H F-$ PECVD, Asian Physics Symposium, Bandung, 2012.

[4] S. Kumar, et al., Journal of Materials Science Letters, 19, 2055 2057 (2000).

[5] Z.F. Ren, et al., Science, 282, 1105 (1998).

[6] A. Latununuwe, dkk., Penumbuhan Nano-katalis Co-Fe Dengan Metode Sputtering, Seminar Nasional Kecenderungan Baru
Fisika dan Pendidikannya 2008, August 7, Malang, Indonesia.

[7] P. Lubis, A. Latununuwe, and T. Winata, Jurnal Nanosains \& Nanoteknologi, Agustus, 1979, 85-89 (2009).

[8] Sukirno, et al., Low Temperature Carbon Nanotube Fabrication using Very High Frequency-Plasma Enhanced Chemical Vapour Deposition Method, Proc. ICSE 2006, Kuala Lumpur, Malaysia.

[9] K.B.K. Teo, C. Singh, M. Chhowalla, and W.I. Milne, Catalytic Synthesis of Carbon Nanotubes and Nanofibers, Encyclopedia of Nanoscience and Nanotechnology. Vol X, 2003.

[10] I. Yuliastuti, A. Subagio, Pardoyo, Jurnal Sains dan Matematika, 23(1), 1-6 (2015). 